\title{
HUBUNGAN PERILAKU DAN LINGKUNGAN FISIK RUMAH DENGAN KEJADIAN TB PARU
}

\author{
Muslimin*
}

\begin{abstract}
ABSTRAK
Faktor perilaku, lingkungan manusia dan pengetahuan menjadikan sumber utama penularan sebuah penyakit. Penularan mudah terjadi apabila keadaan fisik rumah dan sanitasi kurang baik, pertukaran udara bersih dan pencahayaan kurang. Tujuan dalam penelitian ini untuk mengetahui hubungan antara faktor perilaku dan lingkungan fisik rumah dengan kejadian TB Paru pada pasien rawat jalan UPTD Puskesmas Kedawung Kabupaten Cirebon. Penelitian ini merupakan penelitian korelasional dengan pendekatan menggunakan cross sectional. Jumlah sampel dalam penelitian ini sebanyak 33 responden dengan teknik pengambilan sampel secara total sampling. Hasil penelitian menunjukkan bahwa berdasarkan perilaku, sebagian besar responden dengan perilaku aktif sebanyak 22 responden $(66,7 \%)$, berdasarkan lingkungan, sebagian responden dengan lingkungan sehat sebanyak 21 responden $(63,6 \%)$, sebagian besar responden memiliki tingkat pengetahuan yang baik sebanyak 23 responden $(69,7 \%)$ sedangkan faktor yang paling dominan yang berhubungan dengan kejadian TB Paru pada pasien rawat jalan di UPTD Puskesmas Kedawung Kabupaten Cirebon berdasarkan analisis regresi liner berganda menunjukkan faktor pengetahuan $(\mathrm{p}=0,001)$. Kesimpulan dalam penelitian ini yaitu terdapat hubungan menunjukkan adanya hubungan antara faktor perilaku lingkungan fisik rumah dengan kejadian TB Paru pada pasien rawat jalan di UPTD Puskesmas Kedawung Kabupaten Cirebon.

Kata Kunci : Pengetahuan, Perilaku, Lingkungan, TB Paru
\end{abstract}

\begin{abstract}
Behavioral factors, the human environment and the knowledge to make the main source of transmission of a disease. Transmission easily occur if the physical state of the house and poor sanitation, clean air exchange and less lighting. The purpose of the study is to examine the relationship between behavioral factors and the physical environment with the incidence of TB in hospital Kedawung Distritc Cirebon. This study is a correlational study using cross sectional approach. The number of samples in this study were 33 respondents with sampling technique total sampling. The results showed that based on behavior, most of the respondents with active behavior by 22 respondents $(66,7 \%)$, based on the environment , the majority of respondents to a healthy environment as much as 21 respondents $(63,6 \%)$, the majority of respondents have a good level of knowledge as much as 23 respondents $(69,7 \%)$ while the most dominant factors associated with the incidence of TB in hospital UPTD Kedawung Distritc Cirebon by multiple linear regression analysis demonstrated knowledge factor $(p=0.001)$. The conclusion of this research that there is a relationship suggests a link between the physical environment behavioral factors with the incidence of pulmonary tuberculosis in UPTD Kedawung Distritc Cirebon.
\end{abstract}

Keywords : Knowledge, Behavior, Environment, pulmonary TB

* Staf Pengajar Program Studi S1 Kesehatan Masyarakat STIKes Cirebon 


\section{PENDAHULUAN}

World Health Organization (WHO) dalam Annual report on, global TB Control 2003 menyatakan terdapat 22 negara di kategorikan sebagai high-burden countries terhadap TBC, yaitu negara dengan jumlah penderita TBC tertinggi. Estimasi insidence rate untuk pemeriksaan dahak didapatkan basil tahan asam (BTA) positif adalah 115 per 100.000. Data ini menunjukkan bahwa penyakit TBC sebagai penyakit infeksi yang menyebabkan kematian utama di dunia. Penyakit TBC juga meningkat sejalan dengan semakin tingginya kasus beberapa penyakit seperti HIV di seluruh dunia. ${ }^{1}$

Laporan TB dunia oleh WHO, masih menempatkan Indonesia sebagai penyumbang TB terbesar nomor 3 di dunia setelah India dan Cina dengan jumlah kasus baru sekitar 583.000 dan jumlah kematian sekitar 140.000 orang per tahun. Angka kematian akibat TBC (Case Fatality Rate/CRF) di Indonesia mencapai 140 ribu per tahun. Di seluruh dunia setiap tahun terdapat 8,8 juta penderita TBC, 80 persen, di antaranya berada di 22 negara berkembang. Penyakit TBC mengakibatkan kematian 5.000 orang setiap hari atau 1,7 juta orang setiap tahun di dunia. Lima tahun terakhir, Indonesia baru mampu menurunkan angka kesakitan TBC sebanyak 15 per 100 ribu penduduk.

Pemerintah Indonesia telah bertekad memerangi TBC sejak lama. Pengembangan strategi penanganan langsung jangka pendek (Directly Observed Treatment Short-course/ DOTS) sejak tahun 1995 telah terbukti menekan 50\% jumlah penderita TBC di Indonesia. TBC dapat di sembuhkan dengan meminum obat anti-TBC selama 6-8 bulan tanpa berhenti yang dapat diperoleh secara cuma-cuma di Puskesmas. Keberhasilan pengobatan TBC meningkat dari $86,7 \%$ pada tahun 2003 menjadi $88,8 \%$ pada tahun $2004 .^{2}$

Departemen kesehatan RI pada tahun 2001 menyatakan, Indonesia timur adalah kawasan paling banyak penderita penyakit TBC. ${ }^{3}$ Tahun 2006, Departemen Kesehatan RI menyatakan 4 peringkat terbanyak penemuan kasus baru TBC di Indonesia yaitu Sulawesi Utara, Gorontalo, DKI Jakarta dan Jawa Barat. ${ }^{1}$

Penyebab tingginya angka kasus TBC paru yang ada merupakan fenomena yang sering dihubungkan dengan perilaku yang dihubungkan dengan sikap dan pengetahuan. Kurangnya pengetahuan masyarakat tentang penyakit TBC paru, baik berupa pencegahan, penularan, perawatan, serta penanganan baik berupa pengobatan maupun pemeriksaan, merupakan aspek pengetahuan yang tidak dimiliki oleh masyarakat. ${ }^{1}$

Faktor lingkungan, perilaku manusia dan pengetahuan menjadikan sumber utama penularan sebuah penyakit. Penularan mudah terjadi apabila keadaan fisik rumah dan sanitasi kurang baik, pertukaran udara bersih dan pencahayaan kurang. Pencahayaan dari luar sangat penting di dalam rumah karena dapat membunuh bakteri-bakteri patogen di dalam rumah, misalnya basil TB, karena itu rumah yang sehat harus mempunyai jalan masuk cahaya yang cukup. Perilaku juga mempunyai peranan yang begitu besar dalam penyebaran basil TBC, dengan orang berdahak di sembarang tempat mengakibatkan penyebaran kuman melalui udara yang akan terhirup orang lain, perilaku konsumsian rokok.

Kurangnya pengetahuan tentang masalah TB paru juga merupakan faktor resiko tertularnya TB paru. Orang tua sebagai sosok yang paling dekat dengan anak seyogyanya menjaga anak-anaknya dari risiko TB paru dengan cara mengawasi anak-anak agar tidak kontak dengan penderita TB paru dewasa terutama jika terdapat anggota keluarga yang menderita TB, selalu menjaga higienitas anak serta selalu memberikan makanan yang bergizi. Kurangnya penyuluhan TB terhadap orang tua dapat menyebabkan orang tua tidak memiliki pengetahuan yang cukup tentang TB paru dan menyebabkan mudahnya anak tertular TB. ${ }^{4}$

Banyaknya kasus pasien TB paru yang sudah berobat di bagian rawat jalan UPTD Puskesmas Kedawung Kabupaten Cirebon berdasarkan buku register TBC pada tahun 2010 terdapat penemuan kasus sebanyak 12 penderita, tahun 2011 mencapai 81 penderita TB paru sedangkan tahun 2012. Bulan Januari sampai Juli sebanyak 165 penderita TB paru pada anak dan dewasa. Berdasarkan data yang ada menunjukkan adanya peningkatan penderita TB paru dalam setiap tahun. Tujuan 
penelitian untuk mengetahui hubungan perilaku dan lingkungan fisik rumah dengan kejadian TB paru pada pasien rawat jalan di UPTD Puskesmas Kedawung Kabupaten Cirebon Tahun 2012.

\section{METODE PENELITIAN}

Penelitian ini merupakan penelitian korelasional mengenai hubungan antara faktor perilaku dan lingkungan fisik rumah dengan kejadian TB paru pada pasien rawat jalan di UPTD Puskesmas Kedawung Kabupaten Cirebon. ${ }^{5}$ Pada penelitian ini menggunakan metode pendekatan cross sectional yaitu penelitian untuk mempelajari dinamika korelasi antara faktor-faktor risiko dengan efek, dengan cara pendekatan observasi atau pengumpulan data sekaligus pada suatu saat (point time approach) artinya setiap subjek penelitian hanya diobservasi sekali saja. ${ }^{6}$

Populasi dalam penelitian ini adalah pasien TB paru yang sedang menjalani pengobatan rutin di bagian rawat jalan UPTD Puskesmas Kedawung Kabupaten Cirebon sebanyak 33 pasien yang pada periode bulan Desember 2012. Teknik pengambilan sampel yang digunakan adalah total sampling atau pengambilan sampel jenuh adalah pengambilan sampel dari seluruh anggota populasi.

Analisa univariat yang digunakan untuk melakukan analisis distribusi dan persentase karakteristik, variabel faktor perilaku, lingkungan fisik, dan pengetahuan. Analisis data dilakukan dengan analisis deskriptif dalam bentuk tabel distribusi frekuensi.

Analisa bivariat digunakan untuk melihat hubungan antara faktor perilaku, lingkungan fisik rumah, dan pengetahuan dengan kejadian TB paru pada pasien rawat jalan di UPTD Puskesmas Kedawung Kabupaten Cirebon. Dalam penelitian ini untuk melihat faktor perilaku (variabel Xi), lingkungan fisik rumah (variabel X2), dan pengetahuan (variabel X3), dengan kejadian TB paru (variabel Y), dengan menggunakan uji chi square. ${ }^{16}$ Derajat kesalahan yang digunakan dalam penelitian ini adalah 5\% (taraf kepercayaan) untuk melihat hasil kemaknaan perhitungan statistik digunakan batas kemaknaan 0,05 , berarti jika $\rho$ value $\leq 0,05$ maka hasilnya bermakna yang artinya Ha diterima dan jika $\rho$ value $>0,05$ maka hasilnya tidak bermakna yang artinya Ha ditolak.

\section{HASIL PENELITIAN}

\section{Karakteristik Responden}

1. Umur

Hasil penelitian menunjukkan bahwa dari 33 responden, yang berumur $>35$ tahun sebanyak 21 responden $(63,6 \%)$ sedangkan kelompok umur 20 -35 tahun sebanyak 11 responden $(33,3 \%)$ dan kelompok umur $<20$ tahun sebanyak 1 responden $(3 \%)$.

2. Jenis Kelamin

Hasil penelitian menunjukkan bahwa dari 33 responden yang mempunyai jenis kelamin laki-laki sebanyak 14 responden $(42,4 \%)$, dan responden dengan jenis kelamin perempuan sebanyak 19 responden $(57,6 \%)$.

3. Pekerjaan

Hasil penelitian menunjukkan bahwa dari 33 responden yang bekerja sebagai PNS sebanyak 2 responden $(6,1 \%)$, karyawan sebanyak 2 responden $(6,1 \%)$, wiraswasta sebanyak 7 responden $(21,2 \%)$, pedagang sebanyak 3 responden $(9,1 \%)$, buruh/tani sebanyak 11 responden $(33,3 \%)$, dan tidak bekerja sebanyak 8 responden $(24,2 \%)$.

4. Pendidikan

Hasil penelitian menunjukkan dari 33 responden, yang mempunyai latar belakang pendidikan SD sebanyak 10 responden (30,3\%), SMP sebanyak 11 responden (33,3\%), SMA sebanyak 7 responden $(21,2 \%)$, dan PT sebanyak 5 responden $(15,2 \%)$. 


\section{Faktor Perilaku}

Tabel 1 Distribusi frekuensi responden berdasarkan perilaku pada pasien rawat jalan

\begin{tabular}{llcc}
\hline No & Perilaku & Frekuensi & Persentase (\%) \\
\hline 1. & Pasif & 11 & 33,3 \\
2. & Aktif & 22 & 66,7 \\
\hline & Jumlah & 33 & 100 \\
\hline
\end{tabular}

Berdasarkan tabel 1 dapat diuraikan bahwa responden dengan perilaku pasif sebanyak 11 responden $(33,3 \%)$, dan responden dengan perilaku aktif sebanyak 22 responden $(66,7 \%)$.

\section{Faktor Lingkungan Fisik}

Tabel 2 Distribusi frekuensi responden berdasarkan lingkungan fisik pada pasien rawat jalan

\begin{tabular}{llcc}
\hline No & Lingkungan & Frekuensi & Persentase (\%) \\
\hline 1. & Sehat & 11 & 33,3 \\
2. & Tidak sehat & 22 & 66,7 \\
\hline & Jumlah & 33 & 100 \\
\hline
\end{tabular}

Berdasarkan tabel 2 dapat diuraikan bahwa responden dengan lingkungan fisik sehat sebanyak 11 responden $(33,3 \%)$ dan lingkungan tidak sehat sebanyak 22 responden $(66,7 \%)$.

\section{Angka Kejadian TB Paru}

Tabel 3 Distribusi frekuensi responden berdasarkan angka kejadian TB Paru

\begin{tabular}{llcc}
\hline No & Kejadian TB Paru & Frekuensi & Persentase (\%) \\
\hline 1. & Primer & 22 & 66,7 \\
2. & Sekunder & 11 & 33,3 \\
\hline & Jumlah & 33 & 100 \\
\hline
\end{tabular}

Berdasarkan tabel 3 dapat diuraikan bahwa dari 33 responden dengan kejadian TB paru primer sebanyak 22 responden $(66,7 \%)$, dan responden dengan kejadian TB paru sekunder sebanyak 11 responden $(33,7 \%)$. 


\section{Hubungan Antara Perilaku dengan Kejadian TB Paru}

Tabel 4 Tabulasi hubungan antara perilaku dengan kejadian TB paru

\begin{tabular}{|c|c|c|c|c|c|c|c|c|}
\hline \multirow{3}{*}{ Perilaku } & \multicolumn{4}{|c|}{ Kejadian TB Paru } & \multirow{2}{*}{\multicolumn{2}{|c|}{ Total }} & \multirow{3}{*}{$X^{2}$} & \multirow{3}{*}{$P$ Value } \\
\hline & \multicolumn{2}{|c|}{ Primer } & \multicolumn{2}{|c|}{ Sekunder } & & & & \\
\hline & $\mathrm{F}$ & $\%$ & $\mathrm{~F}$ & $\%$ & $\mathrm{~F}$ & $\%$ & & \\
\hline Pasif & 3 & 27,3 & 8 & 72,7 & 11 & 100 & & \\
\hline Aktif & 19 & 86,4 & 3 & 13,6 & 22 & 100 & & \\
\hline Total & 22 & 66,7 & 11 & 33,3 & 33 & 100 & & \\
\hline
\end{tabular}

Berdasarkan tabel 4 dapat diuraikan bahwa pada perilaku pasif dengan kejadian TB paru primer sebanyak 3 responden (27,3\%), dan kejadian TB paru sekunder sebanyak 8 responden $(72,7 \%)$. Sedangkan pada perilaku aktif dengan kejadian TB paru primer sebanyak 19 responden $(86,4 \%)$, dan kejadian TB paru sekunder sebanyak 3 responden $(13,6 \%)$. Hasil Uji statistik menunjukkan Pvalue $<0,05$, berarti terdapat hubungan antara perilaku dengan kejadian TB paru.

\section{Hubungan Antara Lingkungan Fisik dengan Kejadian TB Paru}

Tabel 5 Tabulasi hubungan antara lingkungan fisik dengan kejadian TB paru

\begin{tabular}{|c|c|c|c|c|c|c|c|c|}
\hline \multirow{3}{*}{$\begin{array}{c}\text { Lingkungan } \\
\text { rumah }\end{array}$} & \multicolumn{4}{|c|}{ Kejadian TB Paru } & \multirow{2}{*}{\multicolumn{2}{|c|}{ Total }} & \multirow{3}{*}{$X^{2}$} & \multirow{3}{*}{$P$ Value } \\
\hline & \multicolumn{2}{|c|}{ Primer } & \multicolumn{2}{|c|}{ Sekunder } & & & & \\
\hline & $\mathrm{F}$ & $\%$ & $\mathrm{~F}$ & $\%$ & $\mathrm{~F}$ & $\%$ & & \\
\hline Sehat & 11 & 52,4 & 10 & 47,6 & 21 & 100 & & \\
\hline Tidak sehat & 11 & 91,7 & 1 & 8,3 & 12 & 100 & & \\
\hline Total & 22 & 66,7 & 11 & 33,3 & 33 & 100 & & \\
\hline
\end{tabular}

Berdasarkan tabel 5 dapat diuraikan bahwa pada lingkungan sehat dengan kejadian TB paru primer sebanyak 11 responden $(52,4 \%)$, dan kejadian TB paru sekunder sebanyak 10 responden (47,6\%). Pada lingkungan tidak sehat dengan kejadian TB paru primer sebanyak 11 responden (91,7\%), dan kejadian TB paru sekunder sebanyak 1 responden $(8,3 \%)$. Hasil Uji statistik menunjukkan Pvalue $<0,05$, berarti terdapat hubungan antara lingkungan rumah dengan kejadian TB paru. 


\section{PEMBAHASAN}

\section{Kejadian TB paru}

Hasil penelitian menunjukkan bahwa kejadian TB paru sebagian besar $(66,7 \%)$ dalam kategori TB paru primer. TBC adalah penyakit menular yang disebabkan oleh bakteri Mycobacterium Tuberculosis dan terutama menyerang pada paru-paru. Gejala umum yang dirasakan penderita TBC adalah batuk berdahak selama tiga minggu lebih, kadang-kadang di sertai dahak bercampur dengan darah. Dada penderita juga akan terasa nyeri dan sesak diiringi demam meriang lebih dari sebulan, sering berkeringat di malam hari walaupun tanpa kegiatan. Meski biasanya menyerang paru-paru, TBC juga dapat menyerang tulang, sendi, usus, kelenjar limpa, hingga selaput otak. ${ }^{2}$

Daya penularan dari seorang penderita ditentukan oleh banyaknya kuman yang dikeluarkan dari parunya. Makin tinggi derajat positif hasil pemeriksaan dahak, makin menular penderita tersebut. Bila hasil pemeriksaan sputum (dahak) negatif (tidak terlihat kuman), maka penderita tersebut dianggap tidak menular. Kemungkinan seseorang terinfeksi TB Paru ditentukan oleh konsentrasi droplet dalam udara dan lamanya menghirup udara tersebut.

Hasil penelitian ini dapat disimpulkan bahwa terjadinya TB paru dapat dipengaruhi oleh berbagai faktor seperti halnya faktor dari pola perilaku seseorang tersebut, pendidikan yang terlalu rendah mengakibatkan kurangnya pengetahuan, maka untuk mengantasipasi terjadinya penularan kepada orang lain hendaknya perlu kesadaran akan pentingnya berperilaku sehat seperti menjaga lingkungan, batuk dengan menutup mulut.

\section{Hubungan Perilaku dengan Kejadian TB Paru}

Hasil penelitian menunjukkan bahwa pada perilaku pasif sebagian besar merupakan kejadian TB paru sekunder yaitu sebanyak 8 responden $(72,7 \%)$. Sedangkan pada perilaku aktif sebagian besar merupakan kejadian TB paru primer yaitu sebanyak 19 responden $(86,4 \%)$. Hasil uji statistic menunjukkan terdapat hubungan yang signifikan antara faktor perilaku dengan kejadian TB paru pada pasien rawat jalan di UPTD Puskesmas Kedawung Kabupaten Cirebon .

Perilaku pada hakikatnya adalah suatu aktivitas dari manusia itu sendiri. Kebiasaan merokok akan lebih mudah terserang TB paru. Rokok adalah penyebab utama gangguan pada saluran pernafasan yang kronik (Bronchitis, TB-paru, dan Emfisiema) terhadap hubungan yang erat antara merokok dan penurunan VEP (Volume Ekspirasi Paksa) 1 detik. Penderita perokok banyak yang meninggal karena penyakit di atas. ${ }^{3}$

Secara lebih operasional perilaku dapat diartikan suatu respons organisme atau seseorang terhadap rangsangan (stimulus) dari luar subyek tersebut (15). Respon ini berbentuk 2 macam yaitu:

1. Bentuk pasif adalah respon internal yang terjadi di dalam diri manusia dan tidak secara langsung dapat terlihat oleh orang lain misalkan berfikir, tanggapan, sikap batin dan pengetahuan.

2. Bentuk aktif adalah apabila perilaku itu jelas dapat diobservasi secara langsung.

Perilaku hidup sehat memang menjadi sebuah fenomena pada penderita TB paru rawat jalan di UPTD Puskesmas Kedawung Kabupaten Cirebon, dimana kebiasaan hidup dalam masyarakat masih sedikit kurang memperhatikan segi kesehatan, kebiasaan meludah di sembarang temapat dan kebiasaan-kebiasaan lain yang masih kurang diperhatikan kebersihannya, maka dari itu perlunya adanya pemantauan, penyuluhan, sehingga akan menumbuhkan kesadaran akan hidup sehat yang berawal dari perilaku orang tersebut.

\section{Hubungan antara lingkungan fisik rumah dengan kejadian TB Paru}

Hasil penelitian menunjukkan bahwa pada lingkungan sehat sebagian $(52,4 \%)$ merupakan kejadian TB paru primer dan pada lingkungan tidak sehat sebagian besar $(91,7 \%)$ merupakan kejadian TB paru primer. Hasil uji statistik menunjukkan terdapat hubungan yang signifikan antara faktor lingkungan dengan kejadian TB paru pada pasien rawat jalan di UPTD Puskesmas Kedawung Kabupaten Cirebon . 
Keadaan fisik rumah (ventilasi dan jendela) untuk pertukaran udara bersih dan pencahayaan oleh sinar matahari yang kurang akan menyebabkan keadaan ruangan rumah akan gelap dan lembab, serta keadaan lantai rumah yang kotor dan berdebu akan memudahkan berkembangnya kuman penyakit terutama kuman TB paru, Influenza, Penyakit mata dan lain-lain. Penularan mudah terjadi apabila keadaan fisik rumah dan sanitasi kurang baik, pertukaran udara bersih dan pencahayaan kurang. ${ }^{7}$

Persyaratan kepadatan hunian untuk seluruh rumah biasanya dinyatakan dalam $\mathrm{m}^{2} /$ orang. Luas minimum per orang sangat relatif tergantung dari kualitas bangunan dan fasilitas yang tersedia. Untuk rumah sederhana luasnya minimum $10 \mathrm{~m} 2 /$ orang. Untuk kamar tidur diperlukan luas lantai minimum $3 \mathrm{~m} 2 /$ orang. Untuk mencegah penularan penyakit pernapasan, jarak antara tepi tempat tidur yang satu dengan yang lainnya minimum $90 \mathrm{~cm}$. Kamar tidur sebaiknya tidak dihuni lebih dari dua orang, kecuali untuk suami istri dan anak di bawah 2 tahun. Untuk menjamin volume udara yang cukup, di syaratkan juga langit-langit minimum tingginya $2,75 \mathrm{~m}^{7}$

Lingkungan fisik rumah terkadang kurang begitu diperhatikan bagi masyarakat maupun pasien, sehingga akan menimbulkan lingkungan yang kumuh, kurang adanya pemeliharaan. Hal ini kemungkinan besar disebabkan karena tingkat pendidikan pasien yang mayoritas masih rendah sehingga tingkat pengetahuan mengenai lingkungan fisik rumah masih kurang. Untuk mengantisipasi terjangkitnya penyakit lain dalam keluarga maka perlu adanya konseling, penghargaan lingkungan sehat, sehingga akan memotivasi untuk perabahan dalam mencapai derajat kesehatan yang optimal.

\section{SIMPULAN}

1. Berdasarkan perilaku didapatkan hasil bahwa sebagian besar responden pada perilaku aktif dengan kejadian TB paru primer yaitu sebanyak 19 responden $(86,4 \%)$.

2. Berdasarkan lingkungan fisik rumah sebagian besar responden dengan lingkungan fisik sehat dengan kejadian TB paru primer sebanyak 11 responden $(52,4 \%)$.

3. Hasil uji statistik diperoleh nilai Pvalue $=0,001$, hal ini menunjukkan adanya hubungan yang signifikan antara perilaku dengan kejadian TB paru pada pasien rawat jalan di UPTD Puskesmas Kedawung Kabupaten Cirebon .

4. Hasil uji statistik diperoleh nilai Pvalue $=0,021$, hal ini menunjukkan adanya hubungan yang signifikan antara lingkungan fisik dengan kejadian TB paru pada pasien rawat jalan di UPTD Puskesmas Kedawung Kabupaten Cirebon .

\section{SARAN}

1. Bagi UPTD Puskesmas Kedawung Kabupaten Cirebon .

Penelitian ini dapat dijadikan sebagai acuan secara nyata bagi UPTD Puskesmas Kedawung Kabupaten Cirebon sehingga akan lebih mengoptimalkan pelayanan pada masyarakat dengan cara peningkatan pendidikan kesehatan, penyuluhan dalam masyarakat dan lebih memperkuat komitmen sebagai pelaksana kesehatan untuk memperhatikan dan meningkatkan pelayanan kepada masyarakat baik berupa usaha promotif, preventif, kuratif dan rehabilitatif.

2. Bagi Perawat

Hasil penelitian ini dapat dijadikan sebagai bahan masukan guna meningkatkan kualitas penanganan dan pelayanan khususnya masalah TB paru.

3. Bagi Responden

Hasil penelitian ini dapat dijadikan sebagai wacana penambah ilmu pengetahuan responden yang berkaitan dengan TB paru yang terjadi pada masyarakat luas.

4. Bagi Institusi STIKes Cirebon

Hasil penelitian ini dapat dijadikan sebagai sumber mata ajar dalam perkuliahan yang berkaitan dengan kejadian TB paru, sehingga akan meningkatkan pemahaman bagi mahasiswa khususnya ilmu keperawatan. 
5. Bagi Peneliti Selanjutnya.

Hasil penelitian ini dapat dijadikan sumber informasi dalam penelitian yang akan datang dengan menggunakan metode yang lain sehingga dapat mengeksplor data yang lebih banyak lagi.

\section{DAFTAR PUSTAKA}

1. Nurlianti, Wilda. Tuberkulosis pembunuh ketiga, pasien TBC ke Rumah Sakit Paru cenderung meningkat. 2007.[Diakses tanggal 07 Desember 2014]. Diunduh dari:http//www.ukcoalition.org/tb/wom.

2. Anita. Survey Prevalensi Tuberkulosis. Tahun 2004. (Diakses tanggal 08 Desember 2014) diunduh dari:http://www.ukcoalition.org/tb/wom.

3. Depkes RI. Survey Kesehatan Rumah Tangga.Jakarta:Depkes RI; 2001.

4. Erfandi Pengetahuan dan Faktor-faktor yang Mempengaruhi.[Diakses tanggal 23 Desember 2013]. Diunduh dari: http://for better health.wordpress.com/2009/04/19/pengetahuan-danfaktor-faktor-yang-mempengaruhi/.

5. Arikunto. Prosedur Penelitian suatu Pendekatan Praktek. Jakarta: Rineka Cipta;2006.

6. Nursalam, Siti Pariani. Pendekatan praktis metodologi riset keperawatan. Jakarta: Penerbit Sagung Seto;2001.

7. A. Wawan, Dewi M. Teori dan pengukuran pengetahuan, sikap, dan perilaku manusia. Yogyakarta:Nuha Medika;2010. 